\title{
Do you not see the reason for yourself? Political Withdrawal and the Experience of Epistemic Friction
}

Andrew Schaap, University of Exeter

Forthcoming in Political Studies

The epistemic friction that is generated when privileged subjects are confronted by different social perspectives is important for democratic politics. For it can interrupt their active ignorance about oppressive social relations from which they benefit. However, members of oppressed groups might sometimes prefer not to accept the burden of educating the dominant. In circumstances of structural inequality, withdrawing from privileged subjects' ignorance can be a form of self-preservation. Yet such withdrawal also the potential to induce epistemic friction insofar as it depletes the opportunities for active ignorance to reproduce itself. Herman Melville's tragicomic short story of Bartleby - the legal-copyist who 'would prefer not to' - has been celebrated by philosophers as emblematic of such resistant withdrawal. Interpreting the story as a dramatization of the epistemic friction encountered by its narrator makes vivid how such withdrawal can be political. ${ }^{1}$ 
The next day I noticed that Bartleby did nothing but stand at his window in his dead-wall revery. Upon asking him why he did not write, he said that he had decided upon doing no more writing.

"Why, how now? What next?" exclaimed I, "do no more writing?"

"No more."

"And what is the reason?"

"Do you not see the reason for yourself," he indifferently replied.

(Melville [1853] 1989, 181)

Social inequalities are sustained and reproduced by the active ignorance of privileged social groups, which resists knowledge of oppression. Such ignorance is cultivated through habits of perception that exclude, marginalise and assimilate the experiences, views and concerns of differently situated others, which would otherwise challenge the world-view of the dominant. Consequently, when members of oppressed groups call attention to the structural impediments that limit their political participation, they often appear to privileged subjects to be the problem - to be 'wall-makers' who are creating barriers for themselves (Ahmed 2017: 141). For privileged subjects typically do not see the walls against which members of oppressed groups constantly come up and through which the privileges of a dominant group are maintained.

If active ignorance allows the dominant to comfortably inhabit the unequal social structure from which they benefit, epistemic friction is experienced when the habits of perception that sustain and reproduce this structure are interrupted (Medina 2013). Epistemic friction is generated when marginalized groups succeed in forcing their social perspectives into a public sphere, making perceptible to privileged subjects the institutional walls that they are invested in not seeing. While disconcerting, this experience also affords dominant subjects the opportunity to become more reflexive about their social position. Yet, since the burdens of epistemic friction are borne most heavily by oppressed subjects, activists often respond to ignorant questions from apparently well-meaning privileged subjects with: "It is 
not my job to educate you." Such withdrawal in the face of active ignorance can be a form of self-preservation, conserving one's intellectual, material and affective labour for self-directed ends rather than allowing it to be drained by the demands of the dominant. However, withdrawal also has the potential to induce epistemic friction by disrupting active ignorance from within its own field of possibilities.

The protagonist of Herman Melville's [1853] short story, 'Bartleby, the Scrivener', can be seen as an epistemic anti-hero who enacts such a withdrawal (see Attell 2013). Bartleby is employed as a legal copyist by the unnamed Lawyer who narrates the story. While he begins industriously, within a few days of his employment Bartleby disconcerts his employer by mildly responding to the Lawyer's instructions that he 'would prefer not to.' Each time he politely expresses his preference not to, Bartleby withdraws further from the narrator's social world while becoming an increasingly uncanny presence within it. Having given up copying, Bartleby spends most of his time contemplating the lifeless walls that surround the Lawyer's office, seeming to apprehend in them something that the Lawyer can only dimly intuit. When the Lawyer asks him why he will not work, as Bartleby stares at the wall that the window in front of his desk faces onto, he responds: 'Do you not see the reason for yourself'.

As Mihaela Mihai (2018) discusses, literature can be an important resource to combat active ignorance due to its seductive power to illuminate the epistemic limitations of its readers. Rather than provoking epistemic friction on the part of its readers, however, Melville's story dramatizes the epistemic friction experienced by its narrator. As such, the story itself reveals how withdrawal is not only instrumental (insofar as it is directed toward self-transformation) but can also be world-disclosing (insofar as it interrupts the habits of perception of the dominant). Bartleby does not generate epistemic friction by inserting a marginalized perspective into the social world of the Lawyer. Rather, his withdrawal induces epistemic friction from within the Lawyer's social world by depleting it of opportunities to 
reproduce itself. Consequently, his withdrawal makes the social world of the Lawyer, which the narrator had previously moved so comfortably within, seem unfamiliar to him. While the Lawyer regards himself as a competent, reasonable and compassionate man, Bartleby drives him to distraction, calling into question his self-understanding.

Interpreting the story in terms of the narrator's world-disclosing encounter with Bartleby, moreover, provokes political reflection on the part of its readers about the dynamics of epistemic friction. As readers, we enjoy observing how the experience of epistemic friction reveals to us, even more than to the narrator himself, the limits of the Lawyer's world-view. As such, we might be tempted to stand in moral judgment of the character of the narrator as smug, sentimental and blind to his own complicity in the system that destroys Bartleby. Yet, the story also invites reflection about the stubborn persistence of active ignorance, which prevents such a good-natured interlocutor such as the Lawyer from apprehending the walls that confine Bartleby. The reader's attention thus shifts from the strangeness of Bartleby's behaviour to the 'space of the political': the world of the narrator in relation to which Bartleby's behaviour appears strange (Frank 2013,4). The point of this interpretation, then, is not simply to illustrate political theory by showing how epistemic friction can be induced through withdrawal. Rather it is to draw on this literary work as a source of political thought, which reveals the manifold aspects in which epistemic friction might be experienced (Whitebrook 1995, 57-58; Ingle 1999, 339).

\section{The Politics of Epistemic Friction}

In 2014, Reni Edo-Lodge (2014), the British author and journalist, declared on her BLOG that she was 'no longer talking to white people about race' since she no longer wanted to 
engage with the 'emotional disconnect that white people display when a person of colour articulates our experiences.' She continues:

I just can't engage with the bewilderment and the defensiveness as they try to grapple with the fact that not everyone experiences the world in the way that they do. They've never had to think about what it means, in power terms, to be white - so any time they're vaguely reminded of this fact, they interpret it as an affront. (Edo-Lodge 2014) Understanding structural racism, Edo-Lodge points out, 'still requires people of colour to prioritise white feelings' since most white people become bored, indignant or defensive when their racial privilege is challenged. Edo-Lodge (2014) reflects that while she does not have the power to change the world she can set boundaries and interrupt the entitlement that white people feel towards her by 'stopping the conversation.'

Hannah Gadsby (2018) similarly announced, in her comedy show, Nanette, that she would quit comedy because she was no longer willing to relieve the tension that heteronormal people experience around LGBTQ+ people. Gadsby explains that a joke is essentially a question that has been infused with tension by the comedian, which the surprise answer relieves by making the audience laugh. She points out that she has been learning the art of tension diffusion since childhood when it was not a job or a hobby but a survival tactic. When she used to joke about experiences she had with straight people, who found her difficult to place within their heteronormative world view, she would not talk about her experience of homophobic violence in order for her jokes to work. However, she announces, 'this tension, it's yours. I am not helping you anymore. You need to learn what this feels like because this tension is what not-normals carry inside of them all of the time because it is dangerous to be different' (Gadsby 2018). 
Edo-Lodge and Gadsby both draw attention to active ignorance. Such ignorance does not refer to an arbitrary deficiency of information about certain aspects of social life. Rather, it is socially produced, reflecting and reproducing structural inequalities based on social differences, such as race and sexuality (Bailey 2007: 77). As Charles Mills (2017, 49) describes it, such ignorance is not the 'passive obverse to knowledge' but is 'militant, aggressive, not to be intimidated.' Nor is it confined to the average citizen with which democratic theory is often preoccupied but is also propagated by elites. José Medina (2013: 30-40) highlights how active ignorance is perpetuated by three epistemic vices, to which members of socially dominant groups are prone. Since we enjoy the privilege of being presumed to know (and are therefore used to being accepted as credible speakers), members of privileged groups are prone to arrogance: we tend to over-estimate our own cognitive capacities and find it hard to recognize our own assumptions and biases. Due to the privilege of not needing to know about many aspects of the social world, we are also prone to epistemic laziness: we lack curiosity about social domains that we have learned not to concern ourselves with. Finally, as a consequence of needing not to know about the consequences of structural inequality from which we benefit, members of privileged groups are also prone to closed-mindedness: denying, minimising or distorting the experience of oppression and violence in order to avoid confronting our complicity in structural violence. In conditions of structural inequality, views articulated from the perspective of an oppressed social group thus rarely find a receptive audience. Members of oppressed social groups are less likely to be listened to and often find their views disregarded. They may struggle to articulate their socially situated experiences within the terms of political discourse available to them (Fricker 2007). Moreover, the views they do articulate are vulnerable to appropriation since they are expected to explain themselves on unequal discursive terms (Sanders 1997; Young 2001). 
Challenging active ignorance therefore seems to demand heroic action by members of oppressed groups who must negotiate the unequal speech situation in which political interaction takes place. Despite the material obstacles that work against their political participation, Medina argues that members of oppressed groups have the potential for a subversive lucidity that enables a critical self-questioning of the constitution of society. This is due to what W.E.B. Du Bois called the 'double-consciousness' of marginalized groups who see the world both from their own social perspective and that of the dominant group (Medina 2013: 46, 104f.). Members of oppressed groups are likely to be more aware of the limits of their own social perspective since they are used to it being questioned. They are more likely to be curious about other kinds of knowledge, which they often need in order to navigate the social conditions that disadvantage them. They are more likely to be attentive to other social perspectives since they have no choice but to see reality from the perspective of the dominant group as well was their own. The presence of epistemic counterpoints of marginalised social groups within the public sphere thus has the potential to make visible the active ignorance of privileged groups so that it becomes contestable.

The inclusion of marginalized social perspectives is therefore important for democratic politics because it generates epistemic friction. The notion of epistemic friction indicates how democratic politics is not only a matter of exchanging reasons within an already constituted public sphere. Rather, democratic politics often involves a struggle to (re)constitute the space of the political within which reasons and subjects appear intelligible or nonsensical, reasonable or absurd (see Schaap 2009). As Medina $(2013,18)$ notes, privileged subjects are likely to experience epistemic friction as disempowering since it makes them 'vulnerable, undermines their authority and requires them to pay attention to things that can be uncomfortable.' In contrast, active ignorance is a kind of anti-democratic resistance to the social perspectives of marginalized groups. At an individual level, it entails a reluctance to 
learn from or accept as credible the perspectives of differently situated others. When it structures the context within which different groups interact, it involves practices that censor, silence or inhibit the formation of others' beliefs or cast doubt on their testimony (Medina 2013, 50). As such, active ignorance can be understood as a way of evading or avoiding the experience of epistemic friction (Medina 2013, 10, 185). Indeed, active ignorance characteristically entails what Medina calls 'meta-blindness', which refers not just to an inability to see alternative perspectives but an inability to recognize this inability: the field of the invisible that is constitutive of one's own social perspective (Spanos 2015). ${ }^{2}$

Privileged groups thus depend other social groups and cultures to recognize 'aspects of the social world that they do not see but should care about' (Medina 2013, 76). Epistemic friction has the potential to reveal the prejudices and biases of privileged groups, forcing them to be self-critical, to recognize cognitive gaps and justify their assumptions about the social world (Medina 2013, 50). While Medina stresses the importance of epistemic friction as a condition of possibility for the democratization of the space of the political, however, he does not analyse its political dynamics (Medina 2013, 76, 215; see Mihai 2018, 412, note 4). Mihaela Mihai begins to develop such an account by distinguishing between three registers in which privileged subjects experience discomfort 'when confronted with different pictures of epistemic authority and agency than the ones they are invested in' (Mihai 2018, 398). As Mihai (2018) elaborates, epistemic friction has the potential to illuminate three kinds of limitations that structure experience. Ideational epistemic friction can make us aware of the limits of our received ideas and beliefs through which we make sense of the social world. This includes our understanding of relations of authority and our assumptions about the proper way of doing things, which structure our social interactions. Moral epistemic friction can make us aware of the limits of our sense of justice. This includes what we recognize as an injustice, our sense of what we are mutually entitled to and what we are responsible for. 
Sensorial epistemic friction can make us aware of the limits of our emotional sensibility and social embodiment. This includes how we acknowledge social suffering, extend solidarity to members of different social groups and orient ourselves within social space.

This depiction of epistemic friction as emerging from the confrontation of different social perspectives is consonant with a conception of democratic politics as a struggle for equality between unequal social groups rather than a mutual engagement of social perspectives (see Deranty \& Renault 2009). As such, it is important to recognize the risks and the burdens associated with staging such a confrontation. For, if privileged subjects commonly avoid the experience of epistemic friction through active ignorance and depend on the help of oppressed subjects to overcome their meta-blindness, the burden of epistemic friction seems to rest most heavily with members of oppressed groups (Ahmed 2017). Medina $(2013,116)$ acknowledges that 'oppressed subjects are not obligated to facilitate the communicative and epistemic agency of more privileged subjects if that can worsen their precarious situation and deepen their oppression.' Nonetheless, he highlights how the most responsible epistemic agents are typically also those most disadvantaged by the structural inequality they want to challenge (Medina 2013, 197). In particular, he discusses the role of 'epistemic heroes' who courageously resist active ignorance by testifying to the experience they share with other members of their social group. Epistemic heroes generate epistemic friction in refusing to be silenced (introducing new narratives and cognitive standpoints) and by forcing their way into public spheres (appearing politically through insurrectionary acts and contestatory practices) (Medina 2013, 234). Importantly, transformations of political consciousness are not achieved by isolated actions of individuals but by social networks within which acts of resistance are reiterated. While they emerge from and are supported by social movements, acts by individual epistemic heroes can nevertheless become emblematic insofar as 'they epitomize the daily struggles of resistance of ordinary people within a social 
movement or network' (Medina 2013, 187; 234-248). The words and actions of epistemic heroes thus democratize politics itself.

How, then, might the kind of political withdrawal announced by Gadsby and EdoLodge, generate a similar experience of epistemic friction among privileged subjects? Medina $(2013,101)$ recognizes that sometimes members of oppressed groups 'do not communicate about certain things not because they are hermeneutically incapable of doing so, but because, given the special vulnerabilities they have accrued it is not in their interest to do so.' Reni Edo-Lodge and Hannah Gadsby similarly emphasise how withdrawal is important in order to care for themselves. This aspect of withdrawal leads Jennet Kirkpatrick $(2017,55)$ to characterise withdrawal as instrumental and individual since it is primarily directed toward self-transformation. In contrast, she characterises exit as more political because it is expressive and collective in opposing existing relations of power. However, withdrawal also differs importantly from exit insofar as the agent remains present. While withdrawing their social perspective from the field of representation, they do not leave the political scene but continue to inhabit it. Withdrawal does not directly oppose the institutional arrangements that an actor ceases to co-operate with. Yet it can nonetheless be constitutive (or, better 'destitutive') insofar it 'incites interaction without demanding it' (Ferguson 2002: 9; see Agamben 2014). Such a silent presence may be intensely political insofar as it interrupts the habits of perception of privileged subjects and provokes a reflexive response.

José Medina (2013, 194, 204) generally insists that epistemic fiction comes about through an interactive process in which alternative standpoints are available. In an illuminating discussion of Ralph Ellison's Invisible Man, however, he hints at how epistemic friction might sometimes be exerted 'from the inside' of a dominant social perspective (Medina 2013, 199). The unnamed narrator of the novel observes that white people 'see only my surroundings, themselves, or figments of their imagination, everything and anything 
except me' (Ellison 1952, 7). ${ }^{3}$ Rather than challenging white ignorance, he eventually decides to strategically exploit the blind-spots of active ignorance by becoming 'a supersensitive confirmer of their misconceptions' (Ellison 1952, 384 - cited by Medina 2013, 198). As such, the narrator aims to turn white ignorance on itself in order to make it 'feel its own limitations...the weight of its own ignorance as a burden that makes it dysfunctional or nonfunctional' (Medina 2013, 199). Like the narrator of Invisible Man, we might consider members of oppressed groups who withdraw in the face of the active ignorance of a dominant group to act as epistemic anti-heroes (see Schafer 1968). This is not to suggest that political withdrawal is any less courageous than oppositional political engagement. Rather, such political withdrawal is anti-heroic insofar as refuses to accept the educative role that is often expected of members of oppressed groups in democratic politics: to lead privileged subjects on a journey out of their own ignorance. Yet it is anti-heroic insofar as it is not only selfregarding but has the potential to induce epistemic friction from within the social perspective of privileged subjects.

\section{Active ignorance, disconcerted}

'Nothing so aggravates an earnest person as a passive resistance', declares the unnamed narrator of Melville's short story: a lawyer with chambers on Wall St, who makes a living doing a 'snug business among rich men's bonds and mortgages and title deeds' $(170,156)$. By his own account, the Lawyer is privileged. Moreover, the Lawyer recounts the story of his strange encounter with Bartleby from this privileged perspective, confessing that (almost) all he knows of Bartleby is what his 'own astonished eyes saw' of him (156). Indeed, it is striking that he thinks that it is 'indispensable to an adequate understanding' of Bartleby that he first describes his possessions, making 'some mention of myself, my employees, $m y$ 
business, $m y$ chambers, and general surroundings' (156 - emphasis added; cf. MoretonRobinson 2015).

The Lawyer describes himself as a man who lives by the conviction that the 'easiest way of life is the best' (156). He sees himself as a competent, reasonable and compassionate man, who prides himself on his 'prudence' and 'method' (156). He presents himself as orderly and patient while also able to adapt to circumstance and accommodate the failings and differences of others. He seldom loses his temper or indulges 'in dangerous indignation at wrongs and outrages' (157). The Lawyer's attitude to his employees is paternalistic, reflecting a relation of social inequality. For, as Norman Springer (1965: 411) observes, he sees his employees as 'beneath him in self-control, intelligence and attainment.' His sense of entitlement is based on his social position as employer and pride in his own competence as the originator of the legal documents that his employees merely copy. He therefore enjoys describing each of them at some length to the reader in order to place each according to his own world-view.

The Lawyer's apparently comfortable world is irremediably disrupted when he employs Bartleby as a legal copyist. Unlike his other employees, the Lawyer is unable to place Bartleby, who remains enigmatic to him. The Lawyer first engages Bartleby, despite his strange appearance ('pallidly neat, pitiably respectable, incurably forlorn!'), because he is glad to have an employee of 'so singularly sedate an aspect', who he hopes will balance the flightiness and fieriness of his other employees (164). At first, Bartleby works hard despite his apparent lack of appetite for the job, writing on 'silently, palely, mechanically' (164). Yet, while the other scriveners, Turkey and Nippers, resign themselves to the 'dry, husky' (163) business of copying despite the bad temper it puts them in, only Bartleby eventually declines to do any work at all. The Lawyer's privilege is reflected in his disposition and demeanour when he 'abruptly' calls Bartleby, holding out a copy for him to take in 'natural expectance 
of instant compliance' (165). The Lawyer is taken aback when Bartleby, without getting up from his desk, replies "in a singularly mild, firm voice..."I would prefer not to"” (165). He does so with a 'mild effrontery' that so disarms the Lawyer that he becomes unsure of his own authority. As the story unfolds, however, Bartleby also says he would prefer not to proof-read his own work and would prefer not to run errands. Eventually, he decides that he would prefer not to write at all. 'I have given up copying,' he announces, while taking up residence in the Lawyer's office. When the Lawyer tries to dismiss him, Bartleby says he 'would prefer not to' quit the office, before falling again into silence (183).

Bartleby is sometimes interpreted to be emblematic of an oppressed subject: as an alienated worker (Barnett 1974), as a slave (Donaldson 1970), as a woman (Barber 1977) or as autistic (Sullivan 1976). However, he does not offer his own his own social perspective on Wall street. Rather, he insists that he is 'not particular' (194). With his polite insistence that he 'would prefer not to' Bartleby withdraws and stands aloof not only from his work but also from the epistemic environment that shapes his interaction with the Lawyer. In refusing to make a positive claim about what he would prefer, Bartleby declines to take on the role of epistemic hero. Yet his disengagement nonetheless produces an effect on the Lawyer. Like Hannah Gadsby, we might say that Bartleby prefers not to relieve the Lawyer's tension for him. For the epistemic friction that the Lawyer experiences is not produced through the interaction of two different social perspectives. Rather, it is generated as a consequence of Bartleby's non-cooperation in the communicative exchanges through which the Lawyer strives to confirm his own sense of self as competent, reasonable and compassionate. No doubt Bartleby is different and suffers because of it. Moreover, the narrator intuits that Bartleby sees the world from a different perspective than he does, which he wants to understand. Yet it is by withdrawing from rather than engaging with the Lawyer that Bartleby 'calls into question all that the narrator is' (Springer 1965: 410). 
The Lawyer is disarmed not only by what Bartleby says (since 'I would prefer not to' is not a direct refusal) but how he says it (since his 'singularly mild voice' betrays no sign of insubordination). The Lawyer keeps his other workers in their place, dismissing their resistant speech and actions as petty insubordination due to their rude manners, which he associates with their station as mere copyists. In contrast, the Lawyer recounts how, each time that Bartleby responds, he finds himself further adapting his office arrangements in order to accommodate Bartleby's preferences. Despite his espoused competence, reasonableness and compassion, the Lawyer is infected with a mania that only grows as the story develops. On each occasion that Bartleby says 'I would prefer not to', the Lawyer is taken aback, affronted by Bartleby's intransigence, yet unsure how to respond. While Bartleby remains composed, calm and quiescent, the Lawyer is 'stunned' (165), 'touched and disconcerted' (167), aggravated, irritated and excited (170). He admits that Bartleby has 'seriously affected' him in a 'mental way' (180). He is 'exasperated' (188), loses 'all patience' and flies 'into a passion' (194). Through his strange encounters with Bartleby, the Lawyer thus 'senses his system failing, senses the edges of something beyond him, though at each possible breakthrough the Lawyer transfigures and cuts down these threatening notions of the limits of his own understanding' (Springer 1965: 411). What is it about Bartleby's appearance that affects the Lawyer so profoundly? Following Mihaela Mihai (2018), we can recognize how the narrator experiences epistemic friction on three inter-related registers: ideational (as the Lawyer encounters the limits of his assumptions about proper social conduct); moral (as he becomes aware of the limits of his sense of justice); and, sensorial (insofar as he reflects on the limits of his compassion and social embodiment).

Bartleby's withdrawal generates ideational epistemic friction by making the Lawyer aware of the limits of his social world. The lawyer becomes aware of how his own sense of self-mastery depends on shared assumptions about social relations that structure interactions. 
Bartleby's formula interrupts the Lawyer's speech acts since it does not (quite) make sense in terms of the communicative presuppositions that they rely upon (Deleuze 1997, 73; see Attell 2013: 199f.). For instance, the first time that the Lawyer calls to Bartleby to assist him to proof-read a copy, his action is that of a command of employer to employee. Bartleby's response that he would prefer not to stuns the Lawyer with its mixture of obstinacy and politeness (McCall 1989: 152). The Lawyer wants to interpret Bartleby's response as a refusal. When the Lawyer demands 'Why do you refuse?' Bartleby explains 'I would prefer not to' (167). Bartleby's intransigence is expressed obliquely. He does not refuse to comply with his employer's request outright: he does not say he 'will not' but that he 'he would prefer not to.' The Lawyer would be relieved if Bartleby did not want to. He burns 'to be rebelled against'. But, as Deleuze (1997: 70, 71) discusses, Bartleby's formula is 'neither an affirmation nor a negation...Bartleby does not refuse': he rejects what he does not prefer without affirming a preference.

The Lawyer is disconcerted then, not only by what Bartleby says but how he says it. The social perspectives of members of oppressed groups are often disregarded in social interaction because of how they are communicated, since people from disadvantaged groups often do not speak with the 'epistemological authority' that demands 'acknowledgment of one's arguments' (Sanders 1997: 349). The Lawyer is annoyed by Nippers' ambition, for instance, and dismisses his aspiration to be more than a 'mere copyist' due to the way that he grinds his teeth and hisses rather than speaking well (160). He tolerates Turkey's flighty temper and Nipper's fieriness because he finds them both useful to him as workers. But the narrator experiences Bartleby's withdrawal as disarming precisely because he does not respond in a manner that reflects his social difference from the narrator. Bartleby's face does not show 'a wrinkle of agitation', which could be interpreted as impertinence or similar disposition that is commonly imputed to dismiss or discredit what a dominated subject says 
(166). Rather, he treats his employer's instructions as if 'they were merely polite requests between gentlemen', according to which polite refusal would be a socially appropriate response (Krips 2012, 310). Indeed, the Lawyer regards him as a fellow gentleman with whom he also identifies and to whom he extends certain gentlemanly privileges that he does not afford to his other employees, such as sharing his own room and addressing him by his proper name.

The difficulty posed by Bartleby's recalcitrance, then, is that it does not take the familiar 'forms of petty, working-class insubordination' that the Lawyer tolerates in his other employees (Krips 2012, 311). Rather, the 'flute-like tone' of Bartleby's voice (167) and his 'cadaverously gentlemanly nonchalance' make it seem to the narrator that there is 'nothing ordinarily human about him' (166). His inappropriate response calls into question the presupposition of the speech situation itself. What is the relation of Bartleby to the Lawyer if it is not structured by the role of employer and employee? Bartleby's silence is resistant insofar it withdraws from the assumptions that structure social interaction. By provoking the Lawyer to reflect on his own assumptions about the speech situation, Bartleby's withdrawal both interrupts and depletes the Lawyer's own common sense of the world, which he assumes that they share (Deleuze 1997, 83-84).

The Lawyer demonstrates a certain self-awareness about the likely infelicity of his speech act when he tries to dismiss Bartleby. He assumes that Bartleby will depart once he has instructed him to do so and given him his severance pay. He congratulates himself on his 'masterful management' of the situation (184). Yet, while he has 'built all that he had to say' on that assumption, he realises 'that assumption was simply my own, and none of Bartleby's. The great point was, not whether I had assumed that he would quit me, but whether he would prefer to do so. He was more a man of preferences than assumptions' (184). Bartleby's behaviour appears strange because the Lawyer has mistakenly assumed that he and Bartleby 
follow the same conventions in order to cooperate in the same practices (Attell 2013: 200). When he returns to his office to find Bartleby still there, he is thunderstruck. He wonders at the ineffectiveness of the 'doctrine of assumptions' according to which he usually lives his life. He is driven to the end of his wits when, after demanding that Bartleby resign, Bartleby replies "'I would prefer not to quit you" ...gently emphasising the not' (186). ${ }^{4}$ Far from exiting, Bartleby is 'always there' (173): he 'never leaves' (169) but comes to appear as a 'fixture' (182) in the Lawyer's office, a 'perpetual sentry in the corner' (169) where he 'stands mute and solitary' (184). Bartleby disconcerts the Lawyer since he remains on his premises even while he declines to accept the premises of the world of Wall Street in which he continues to dwell.

Bartleby's withdrawal generates moral epistemic friction by leading the Lawyer to question his own sense of justice. The Lawyer sees himself as a reasonable man but begins to doubt whether he is in the right, after all. The ambiguity of Bartleby's formula confounds the Lawyer's expectations about the proper exchange of reasons. While the Lawyer reasons with Bartleby, explaining why he should be willing to proof-read his own documents, he observes that Bartleby seemed to consider carefully everything he said and understand its meaning yet 'some paramount consideration prevailed with him to reply as he did' (167). When the Lawyer asks what Bartleby means, Bartleby simply repeats 'I would prefer not to' (166). When asked why he refuses, Bartleby answers 'I would prefer not to' (167). His formula thus functions not only as a statement of what he does not want to do but as an enigmatic explanation of why he wants not to do it.

The Lawyer insists that since his requests 'are made according to common usage and common sense' (168) they are 'perfectly reasonable' (172). In contrast, he thinks that Bartleby is browbeating him in an 'unprecedented and violently unreasonable way' (168). He finds it difficult not to 'bitterly exclaim upon such perverseness - such unreasonableness' 
(173). Yet while Bartleby's language is not reasonable neither is it wholly unreasonable since it causes the Lawyer to doubt the reasonableness of his own position. The Lawyer thus begins to 'stagger in his own plainest faith' and to wonder if 'all the justice and all the reason is on the other side' (168). While he appeals to his subordinates to assure him that he has right on his side they too seem to oscillate between enjoying the spectacle of Bartleby confounding the Lawyer and resenting him for free-riding on his co-workers $(168,171) .^{5}$ Yet Bartleby's apparent unreasonableness only increases as the story unfolds. The Lawyer implores Bartleby 'to be a little reasonable' to which, of course, Bartleby replies, hilariously, that, at present, he would 'prefer not to be a little reasonable' (180). After a time, it becomes accepted within the office that Bartleby 'was permanently exempt from examining the work done by him' and that he 'was never on any account to be dispatched on the most trivial errand of any sort' and 'even if entreated' to do so, 'it was generally understood that he would prefer not to' (172-3).

When the Lawyer happens to stop by his chambers on a Sunday morning, he is surprised to find the door locked from the inside. He is further taken aback when Bartleby opens the door in a dishevelled state, 'saying quietly that he was sorry, but he was deeply engaged just then, and - preferred not admitting me at present' (174). The 'unaccountable scrivener' is impervious to the legitimate expectations of the Lawyer (174). At the same time, however, the narrator insists that 'it was not to be thought for a moment that Bartleby was an immoral person' (175). When the Lawyer tries to make conversation with Bartleby about his background the following day, in order to understand why he has taken up residence in his chambers, Bartleby, of course, says he would prefer not to tell his employer anything about himself and that he would prefer 'to be left alone here' (181). When the Lawyer asks him to leave his office with severance pay, Bartleby says he would prefer not to resign or to accept the money. When the Lawyer demands 'What earthly right have you to stay here? Do you pay any rent? Do you pay my taxes? Or is this property yours?' Bartleby responds with 
silence (187 - emphasis added). While directed at Bartleby, the Lawyer's questions about the rightness and reasonableness of Bartleby's actions rebound on himself and his own sense of entitlement, which he had previously taken for granted.

Bartleby's withdrawal generates sensorial epistemic friction, revealing to the Lawyer the limits of his compassion and leading him to become uncomfortable in his own skin. The Lawyer sees himself as a benevolent man but comes to doubt himself and his place in the world since he is unable to help Bartleby. He senses that Bartleby finds himself confined by the world that he more easily inhabits and is perplexed that he is unable to help him feel at ease. The story takes place in the Lawyer's office on Wall Street, the financial centre of New York City and the office itself is surrounded by the walls of adjacent buildings. The view from the window at one end of the office is onto a white wall, which the Lawyer explains, is 'deficient in what landscape painters call "life", while the view from the other end of the office is of a blackened brick wall that is 'pushed up to within ten feet of [the] window panes' (157). The Lawyer assigns Bartleby to a desk alongside a third, small side window that looks onto a wall only three feet away. While he partitions off the corner of the room with a screen to provide privacy for himself, as the story unfolds he describes Bartleby's corner of the office as his 'hermitage' from which he would appear ghost-like only after being summoned thrice $(169,172,187,188)$. Increasingly Bartleby 'would stand looking out, at his pale window behind the screen upon the dead brick wall' (177). Bartleby would stand 'motionless' $(163,177)$ and 'immovable' (189) for long periods that the Lawyer characterises as one of his 'dead-wall reveries' $(177,181,188)$. When the Lawyer demands to know why Bartleby has ceased to copy as he stares at the wall, Bartleby replies indifferently, 'Do you not see the reason for yourself' (181). The Lawyer wonders whether Bartleby sees something in the wall that he does not, which would make Bartleby's intransigence comprehensible. Yet he quickly 
passes over this by speculating that Bartleby's vision has become impaired due to the poor light that the small window affords (181).

Bartleby forces the narrator to recognize the limit of his compassion. On the one hand, he feels 'unmanned' by the fact that his own employee is able to 'dictate to him, and order him away from his own premises' (174). His resentment builds so that he falls into 'sudden spasmodic passions' with Bartleby (173) and feels murderous toward him. He fears that Bartleby might outlive him and claim possession of his office by 'perpetual occupancy' (190). He thus comes to see Bartleby as a burden and wants to rid himself of the 'intolerable incubus' (i.e. a demon in male form, which seduces women in their sleep) (190). On the other hand, the Lawyer decides that Bartleby is suffering from an 'innate and incurable disorder' affecting his soul (178). He decides that he might 'cheaply purchase a delicious self-approval' by accommodating Bartleby's strange behaviour (170). But when the Lawyer attempts to befriend Bartleby by 'gently calling to him' (178), he is met with no reply. When he clarifies that he is 'not going to ask him to do anything' but simply wishes to speak to him, Bartleby says that he prefers not to tell the Lawyer anything about himself. When the Lawyer asks what reasonable objection Bartleby could have to speaking with him in a friendly way, Bartleby says that he would prefer to give no answer before withdrawing in silence. The Lawyer reflects on the 'terrible' truth of the limits of benevolence as his first feelings of sincerest pity and 'fraternal melancholy' toward Bartleby turn to fear and repulsion in the face of 'a certain helplessness of rectifying excessive and organic ill' (178). He therefore resigns himself to accepting the situation without trying any longer to understand Bartleby or relieve his suffering.

Yet, as Leo Marx (1953: 614) observes, the social order itself determines Bartleby's fate. For it is only the comments of his friends and clients, who recognize how Bartleby makes a mockery the Lawyer's position and status, which forces him to act. Since he is 
unable to dismiss or evict Bartleby, the Lawyer relocates his chambers to another address entirely, leaving Bartleby behind. While Bartleby does not attempt to follow the Lawyer to his new premises, he is soon contacted by the new occupants of his old chambers asking for his assistance to remove Bartleby who, he is told, 'persists in haunting the building generally' and 'refuses to do anything, he says he prefers not to; and he refuses to quit the premises' $(193,192)$. As Marx $(1953,615)$ observes, at this point in the story Bartleby's withdrawal has 'taken on an explicitly revolutionary character.' For, as the landlord informs the Lawyer: 'everybody is concerned; clients are leaving the offices; some fears are entertained of a mob' (193).

The narrator's experience of sensorial friction is embodied, as he becomes increasingly disoriented. Prior to his strange encounter with Bartleby, the narrator takes for granted the 'socially contingent comfort' he feels in being at home in his own body (Shotwell 2009, 64). This is reflected in his self-description as a self-possessed and temperate man (156-157). In contrast to his own easy nature, he notices how Nippers suffers from indigestion, which is reflected in his 'occasional nervous testiness and grinning irritability' so that he finds it impossible to adjust his table to a comfortable height. Moreover, in contrast to his own self-restraint, he observes how the 'self-indulgent habits' of Turkey lead him to become obstreperous in the afternoon when there was 'strange, inflamed flurried flighty recklessness of activity about him' (158). Yet, by the end of his story, the narrator also finds himself in a 'state of nervous excitement' (187) and fears that he might lose control to the point of murdering Bartleby if left alone with him in his office. He no longer describes his chambers as a 'snug retreat' (156) that protects and insulates him (see DiAngelo 2011). Rather he likens his office to 'a building entirely unhallowed by domestic associations - an uncarpeted office, doubtless, of a dusty, haggard sort of appearance' (187). With this shift in perception, the narrator perhaps comes to apprehend his surroundings from a perspective 
closer to Bartleby's. The narrator comes to feel so out of place that, after failing to persuade Bartleby to leave his old offices (and even offering to take Bartleby home with him), he takes flight in his carriage for a few days to the upper part of town, leaving his other employees to take care of his business (195). While deserting the stationary Bartley, the Lawyer finds himself on the run, almost living in his carriage for some time while paying 'fugitive visits' to the part of town he previously moved within so freely (195). On returning to Wall St, the Lawyer is informed by a note from his landlord, which he opens with 'trembling hands' (196), that the police had been called and removed Bartleby to prison.

The Lawyer learns that Bartleby did not resist his arrest but 'in his pale unmoving way, silently acquiesced' (196). When the Lawyer visits Bartleby at the Tombs he finds him 'standing all alone in the quietest of yards, his face towards a high wall' (197). When the Lawyer says his name, Bartleby responds, 'I know you... and I want nothing to say to you' (197). When the Lawyer suggests that the prison is not such a vile place, pointing to the sky and the grass as signs of life, Bartleby replies simply 'I know where I am,' after which he refuses to say anything more. The Lawyer arranges to pay one of the prison guards who calls himself the 'grub-man' to ensure that Bartleby is well-fed. However, when asked what he will have for dinner, Bartleby replies to the grub-man, 'I would prefer not to dine today', explaining that it would 'disagree' with him since he is 'unused to dinners', before he returns to his position, 'fronting the dead-wall' (198). When the Lawyer returns to the Tombs a few days later, he finds Bartleby, apparently asleep, 'strangely huddled up at the base of the wall', before realising that he is dead (199). The fraternal melancholy that Bartleby induces in the Lawyer rings hollow in the final trite declaration of the narrator: 'Ah Bartleby! $\mathrm{Ah}$ humanity!' (200).

\section{The World-Disclosing Potential of Epistemic Friction}


That Bartleby dies alone in the Tombs seems to highlight the limitations of interpreting his withdrawal as an effective mode of politics. Unlike Medina's epistemic heroes who always act within chains of action, Bartleby appears as a solitary and lonely figure. Moreover, far from being an act of self-care, his withdrawal from the Lawyer seems to involve a withdrawal from all human society to the point that he can no longer survive at all. The story itself suggests, then, that we should not be too quick to interpret withdrawal as a mode of resistance rather than a symptom of social suffering (see McNay 2014). Indeed, as Hardt and Negri (2000: 203-204) highlight, the solitary nature of Bartleby's withdrawal seems to end only in 'social suicide' (cf. Oliver 1945).

Withdrawal arguably only becomes political when it is undertaken out of concern not just for the self but the world shared with others (Krips 2012: 309). While individuals such Edo-Lodge and Gadsby might act as epistemic anti-heroes, their individual actions are indeed supported by social networks that provide discursive and material resources to be politically intelligible and effective. Withdrawal, then, seems unlikely to generate epistemic friction in the absence of positive claims articulated by social movements, which also challenge active ignorance directly. This interpretation seems to vindicate Hardt and Negri's claim that withdrawal can only be the first step in an emancipatory politics. For, if the gesture of 'subtracting ourselves from a relationship of domination' is essential for any emancipatory politics, they suggest that it risks remaining empty unless it is accompanied by an affirmative moment of constituting power (Hardt \& Negri 2000: 204; see Attell 2003: 210-213). Indeed, in contrast to Bartleby, both Gadsby and Eddo-Lodge stage withdrawals in order to establish the terms on which they might be prepared to engage. Moreover, both continue to confront active ignorance on their own terms, with Eddo-Lodge producing her podcast 'About Race' and Hannah Gadsby returning with her comedy show Douglas. 
For Slavoj Žižek (2006: 382), however, Bartleby’s passive resistance is 'not merely the first, preparatory stage, for a second, more "constructive," work of forming a new alternative order; it is the very source and background of this order, its permanent foundation.' For Hardt and Negri, the negative moment of Bartleby's refusal would be overcome through the actualization of his freedom through positing an alternative social order. For Žižek, in contrast, Bartleby’s potential for an active resistance is not immanent to his negation of the existing order. ${ }^{6}$ Rather, Bartleby intimates a kind of politics that 'opens up a new space outside the hegemonic position and its negation' (Žižek 2006: 382). For, in declining to comply with his employer's instruction, Bartleby 'does not say that he doesn't want to do it; he says that he prefers (wants) not to do it' (Žižek 2006: 381). In doing so, he gestures toward a politics would decline 'all the forms of resisting which help the system to reproduce itself by ensuring our participation in it' (Žižek 2006: 383). Giorgio Agamben $(2014,71)$ similarly points to the 'destitutent power' exemplified by Bartelby's withdrawal, which would 'deactivate every juridical and social property, without establishing a new identity' (cf. Agamben 2009; Whyte 2009).

When interpreted along these lines, Melville's story indicates how withdrawal from what Mariana Ortega (2006) calls ‘loving, knowing ignorance' might generate epistemic friction in the absence of a positive demand. An acute risk of participating in political discourse as a member of an oppressed group is that one's words and actions are colonized by a hegemonic discourse, thereby re-inscribing the privileged perspective that epistemic friction is supposed to call into question (see Sanders 1997; Young 2001). However, as Michael Rogin (1979, 195-196) observes, in 'refusing to explain himself' Bartleby both 'protects himself from colonization' and 'drains his surroundings of the humanity in which the lawyer would like to believe.' Withdrawal is potentially world-disclosing, then, insofar as it makes visible how active ignorance structures the communicative setting in which deliberative 
exchanges take place. Otherwise isolated acts by epistemic anti-heroes become political, then, when they disrupt the sensibilities of their audience (Krips 2012, 310). In this way, withdrawal is not only instrumental and individual as an act of self-care; it becomes political through its power to turn the tension that members of oppressed groups experience everyday back onto the dominant.

Yet, it would also be implausible to interpret the story simply as a depiction of the Lawyer's journey out of active ignorance and into epistemic lucidity. The Lawyer sees himself as a decent, patient and generous and wants to confirm his own self-perception in recounting his strange encounter with Bartleby. While he intuits the limitations of his own social world due to the epistemic friction he encounters, he remains 'irrevocably wedded to what he thinks he is' (Springer 1965, 418). Indeed, the Lawyer does end up placing Bartleby in a certain way when he assures the prison officer that he was 'a perfectly honest man, and greatly to be compassionated, however unaccountably eccentric' (196; see Springer 1965; 417). Consequently, he is able to relieve some of the epistemic friction he had encountered by maintaining his respect and compassion for Bartleby, despite being implicated in Bartleby's suffering and death (195). As Springer (1965: 413) observes: 'When he is done with Bartleby he can, with some uneasiness, congratulate himself on his handling of a situation that was in the main beyond him.'

Despite his good intentions and his effort to be charitable and decent, one thus also senses in the Lawyer's narrative, the three epistemic vices highlighted by Medina. Despite his desire to find out what is wrong with Bartleby, the Lawyer remains epistemically arrogant in presuming to know what is good for him: 'Either you must do something or something must be done to you' (194). Despite his sense of responsibility toward Bartleby, the Lawyer remains epistemically lazy in not needing to know what would become of him when he relocated office to escape him: 'I now strove to be entirely care-free and quiescent; and my 
conscience justified me in the attempt' (195). Despite his attempt to ensure Bartleby is welllooked after in prison, he remains epistemically closed-minded in needing not to know about the suffering he experiences: 'And see, it is not so sad a place as one might think. Look, there is a sky, and here is the grass' (197).

However, as Dan McCall highlights, the tendency of some critics to chastise the Lawyer as self-absorbed, self-deceived and blind to his own complicity in the system that destroys Bartleby, flatten out what is most engaging in the story. Such readings typically rely on a kind of ideology critique, the aim of which is to see through the unreliable narrator in order to 'expose him for the inadequate and misguided man he really is' (McCall 1989: 103). Interpreting the story as a dramatization of the Lawyer's experience of epistemic friction, in contrast, enables the reader to identify with the narrator in his struggle to understand Bartleby even as we take subversive pleasure in watching him unravel (McCall 1989: 100). Rather than stand in judgement of the Lawyer as an epistemic villain, we can instead empathise with the psychological drama he recounts of his own dawning self-awareness of his failure to understand Bartleby. For it is through his own story that the world of the Lawyer is disclosed to the reader as he describes how, despite his initial over-estimation of his own cognitive competencies, they fail him when confronted by the enigmatic Bartleby (McCall 1989: 108). The effect of Bartleby's formula on the narrator is to induce in him a self-doubt that almost drives him crazy and leads him to an intensive self-examination that he shares with his readers (McCall 1989: 128). The Lawyer's narrative is thus driven by his effort to understand what is wrong with Bartleby. However, the world-disclosing power of story lies in what it reveals about the narrator. Rather than trying to explain why Bartleby withdraws, therefore, the reader's attention shifts to the narrator's experience of estrangement, discomfort and disorientation from the social world that he once moved so effortlessly within (Rogin 1979, 196). As Dan McCall $(1989,144)$ observes: 'Bartleby throws you back on yourself in 
sputtering exasperation and self-justifying. You cannot 'fix' Bartleby, so one thing you do is talk about yourself- it's not $m y$ fault, I'm a good guy, don't look at $m e$.' As readers, we take pleasure in observing how all the Lawyer's best efforts to make Bartleby see reason fail and his safe world is thrown into question.

But to look to the story primarily as a moral lesson on how to cultivate epistemic virtues and eradicate epistemic vices would also be to miss its world-disclosing power (Mrovlje 2019). When interpreted with an aesthetic sensibility, the story rather enables a reflexivity on the part of the reader about the limits and possibilities of the political responsiveness that withdrawal might provoke. The distance that the reader enjoys as spectator of the Lawyer's encounter with Bartleby enables political reflection on how the experience of epistemic friction might be seized as an opportunity for privileged subjects to arrest active ignorance while remaining attentive to the ever-present risk of reproducing it. For the story also intimates the lengths that privileged subjects will go in their need not to know about oppressive social relations as we witness the Lawyer's response when Bartleby says: 'don't you see the reason for yourself.' Rather than contemplate more carefully the wall with which Bartleby is preoccupied and reflect more deeply on the field of the invisible structures his own vision, the Lawyer surmises from the 'dull and glazed' look in his eyes that it is Bartleby's vision, which must be 'temporarily impaired' (181).

\section{References}

Agamben G (1999) Bartleby, or On Contingency. In: Potentialities: Collected Essays in Philosophy. Stanford: Stanford University Press.

Agamben G (2014) What is destitutent power? Environment and Planning D: Society and Space 32: 65-74.

Ahmed S (2010) Feminism and the History of Happiness. Signs 35(3): 571-594.

Ahmed S (2017) Living a Feminist Life. Durham: Duke University Press. 
Attell K (2013) Language and Labour, Silence and Stasis: Bartleby among the Philosophers. In: Frank J (ed) A Political Companion to Herman Melville. Lexington: University Press of Kentucky.

Balfour, L (2013) What Babo Saw: Benito Cereno and the World We Live In. In: Frank J (ed) A Political Companion to Herman Melville. Lexington: University Press of Kentucky.

Barnett, L (1974) Bartleby as Alienated Worker. Studies in Short Fiction 11(4): 379-385.

Cooke, M (2014) Truth in narrative fiction: Kafka, Adorno and beyond. Philosophy and Social Criticism 40(7) 629-643.

Cornwell E (1982) Bartleby the Absurd. The International Fiction Review 9(2): 93-99.

Deleuze, G (1997) Bartleby; or, The Formula. In: Essays Critical and Clinical, trans. Daniel Smight W. Minneapolis: University of Minnesota Press, 68-90.

Deranty, J-P \& E Renault (2009) Democratic Agon: Striving for Distinction or Struggle against Domination and Injustice. In: Law and Agonistic Politics, ed. Andrew Schaap. Farnham: Ashgate.

DiAngelo, R (2011) White Fragility. International Journal of Critical Pedagogy 3(3): 54-70.

Donaldson, S (1986) The Dark Truth of the Piazza Tales. PMLA 85(5): 1082-1086.

Dotson K (2011) Tracking Epistemic Violence, Tracking Practices of Silencing. Hypatia 26(2): 236-257.

Edo-Lodge R (2014) Why I'm no longer talking to white people about race. BLOG post, 22 February, http://renieddolodge.co.uk/why-im-no-longer-talking-to-white-peopleabout-race/, accessed 11/9/2018.

Edo-Lodge R (2017) Why I'm No Longer Talking to White People about Race. London: Bloomsbury.

Egbert O (1945) A Second Look at "Bartleby." College English 6(8): 431-439.

Ellison R (2001) Invisible Man. Harmondsworth: Penguin.

Ferguson K (2003) Silence: A Politics. Contemporary Political Theory 2(1): 49-65.

Frank J (2013) Introduction. American Tragedy: The Political Thought of Herman Melville. In: Frank J (ed) A Political Companion to Herman Melville. Lexington: University Press of Kentucky.

Fricker, M (2007) Epistemic Injustice: Power and the Ethics of Knowing. Oxford: Oxford University Press.

Gadsby H (2018) Nanette, TV special directed by Jon Olb \& Madeleine Parry. Netflix, released 19 June. Transcript available: https://scrapsfromtheloft.com/2018/07/21/hannah-gadsby-nanette-transcript/, accessed $11 / 9 / 2018$. 
Hardt, M \& Negri A (2000) Empire. Cambridge, MA: Harvard University Press.

Hardwick E (1981) Bartleby and Manhattan. The New York Review of Books, 16 July.

Ingle S (1999) Politics and Literature: Means and Ends in Koestler. Political Studies 47(2): 329-344.

Krips H (2012) The Politics of Overcomformity: Bartleby Meets Žižek. Communication and Critical/Cultural Studies 9(3): 307-316.

Lindahl H (2013) Fault Lines of Globalization: Legal Order and the Politics of A-Legality. Oxford: Oxford University Press.

Marx L (1953) Melville's Parable of the Walls. The Sewanee Review 61(4): 602-627.

McCall D (1989) The Silence of Bartleby. Ithaca: Cornell University Press.

McNay L (2014) The Misguided Search for the Political. Cambridge: Polity.

Medina J (2013) The Epistemology of Resistance: Gender and Racial Oppression, Epistemic Injustice, and Resistant Imaginations. New York: Oxford University Press.

Melville H [1853] (1989) Bartleby, The Scrivener: A Story of Wall-Street. In: Dan McCall, ed. The Silence of Bartleby. Ithaca: Cornell University Press.

Mihai M (2018) Epistemic marginalisation and the seductive power of art. Contemporary Political Theory 17(4): 395-416.

Mills C (2017) White Ignorance. In: Black Rights/White Wrongs: The Critique of Racial Liberalism. New York: Oxford University Press.

Moreton-Robinson A (2015) The White Possessive: Property, Power, and Indigenous Sovereignty. Minneapolis: University of Minnesota Press.

Mrovlje, M (2019) Beyond Nussbaum's Ethics of Reading: Camus, Arendt and the Political Significance of Narrative Imagination. The European Legacy 24(2): 162-180.

Ortega N (2006) Being Lovingly, Knowingly Ignorant: White Feminism and Women of Colour. Hypatia 21(3): 56-74.

Rogin, M (1979) Subversive Genealogy: The Politics and Art of Herman Melville. Berkeley: University of California Press.

Sanders, L (1997) Against Deliberation. Political Theory 25(3): 347-376.

Schaap, A (2009) The absurd proposition of Aboriginal Sovereignty. In: Law and Agonistic Politics, ed. Andrew Schaap. Farnham: Ashgate.

Schafer, W J (1968) Ralph Ellison and the Birth of the Anti-Hero. Critique: Studies in Contemporary Fiction 10(2): 81-93. 
Shotwell, A (2009) A Knowing That Resided in My Bones: Sensuous Embodiment and Genderqueer Social Movement. Agency and Embodiment, ed. S Sherwin, S Campbell, \& L Meynell (eds.) University Park: Penn State University Press.

Spanos W V (2015) "Benito Cereno" and "Bartleby, the Scrivener": Reflections on the American Calling. In William V Spanos, Humanist Criticism and the Secular Imperative, ed. Daniel T O’Hara \& Michelle Martin. Evanstone, IL: Northwestern University Press.

Springer N (1965) Bartleby and the Terror of Limitation. PMLA 80(4): 410-418.

Young I M (2001) Activist Challenges to Deliberative Democracy. Political Theory 29(5): 670-690.

Whitebrook M (1995) Politics and literature? Politics 15(1): 55-62.

Whyte J S (2009) 'I would prefer not to': Giorgio Agamben, Bartleby and the potentiality of the law. Law and Critique 20(3): 309-324.

Žižek S (2006) The Parallax View. Cambridge: MIT Press.

${ }^{1}$ Earlier versions of this paper were presented at workshops on 'Resistances: Rethinking the Politics of Reconciliation', Monash University, Prato, 21-23 June 2017 and 'Doing Democracy Differently', McMaster University, Hamilton, 21-23 March 2019. Thanks to participants at both events for pushing me to think more carefully about active ignorance. I am particularly grateful to Ditte Madsen, Keith Breen, Mihaela Mihai, Bonnie Honig and the two anonymous reviewers for their helpful comments.

${ }^{2}$ Charles Mills (2017) refers to one of Melville's other well-known short stories, Benito Cereno, as exemplifying white ignorance. In the story, Captain Amasa Delano encounters a Spanish slave ship in distress and comes to the aid of its Captain Benito Cereno. While he notices that Cereno acts strangely and inappropriately as the ship's captain and he is troubled by the number of black people crewing the ship, Delano fails to apprehend that the slaves have actually taken command of the ship and that Cereno is being held hostage by his apparently faithful friend, Babo. See Balfour (2013) and Spanos (2015).

${ }^{3}$ Significantly, Ellison quotes Benito Cereno as an epigraph to his novel: "You are saved," cried Captain Delano, more and more astonished and pained; "you are saved: what has cast such a shadow upon you?" Cereno's answer, which Ellison omits, is: 'The Negro'. As William Spanos (2008, 441-442) observes, 'What Benito Cereno "sees" as he speaks this simple stunning word is too complicated for any easy discursive answer. But we can get at its existential force indirectly by suggesting that it and the resonant silence surrounding its utterance bring to sudden and intensely ominous - spectral - visibility everything that Captain Delano's discourse...during that day on the San Dominick left necessarily unsaid, everything that...was invisible to his vision.'

${ }^{4}$ As Deleuze (1997: 73) observes, all of the Lawyer's 'hopes of bringing Bartleby back to reason are dashed because they rest on a logic of presuppositions according to which an employer 'expects' to be obeyed, or a kind friend listened to, whereas Bartleby has invented a new logic, a logic of preference, which is enough to undermine the presuppositions of language as a whole.'

${ }^{5}$ The first time he asks them, Turkey blandly agrees that he thinks the Lawyer is right, while Nippers ventures that he should 'kick him out of the office' and Ginger Nut suggests that 
Bartleby is 'a little luny' (168). A few days later, Turkey is so incensed by Bartleby's withdrawal that he offers to 'black his eyes' (171). Nippers is more measured, saying that it is for the Lawyer to decide if Bartleby should be dismissed, while agreeing that his conduct is 'quite unusual, and indeed unjust' toward his fellow employees, although it might 'only be a passing whim' (171).

${ }^{6}$ As Attell $(2013,218)$ explains, for Žižek Bartleby is, rather, 'the embodiment, or the placeholder, of a negativity or potentiality that exists and persists as such, and does not simply efface itself or disappear in the onto-political drama of becoming.' 